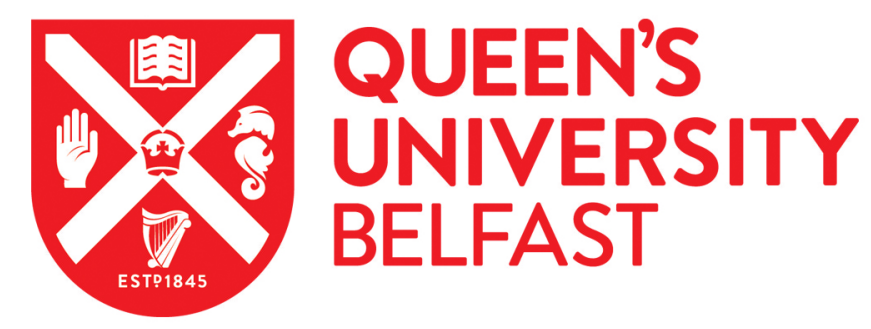

\title{
Punitive Reform and the Cultural Life of Punishment: Moving from the ASBO to its Successors
}

Brown, K. J. (2020). Punitive Reform and the Cultural Life of Punishment: Moving from the ASBO to its Successors. PUNISHMENT \& SOCIETY-INTERNATIONAL JOURNAL OF PENOLOGY, 22(1), 90-107. https://doi.org/10.1177/1462474519831347

Published in:

PUNISHMENT \& SOCIETY-INTERNATIONAL JOURNAL OF PENOLOGY

Document Version:

Peer reviewed version

Queen's University Belfast - Research Portal:

Link to publication record in Queen's University Belfast Research Portal

Publisher rights

(c) 2019 The Author. This work is made available online in accordance with the publisher's policies. Please refer to any applicable terms of use of the publisher.

\section{General rights}

Copyright for the publications made accessible via the Queen's University Belfast Research Portal is retained by the author(s) and / or other copyright owners and it is a condition of accessing these publications that users recognise and abide by the legal requirements associated with these rights.

Take down policy

The Research Portal is Queen's institutional repository that provides access to Queen's research output. Every effort has been made to ensure that content in the Research Portal does not infringe any person's rights, or applicable UK laws. If you discover content in the Research Portal that you believe breaches copyright or violates any law, please contact openaccess@qub.ac.uk. 


\title{
Punitive Reform and the Cultural Life of Punishment: Moving from the ASBO to its Successors
}

\section{XXXXXX}

\begin{abstract}
This paper explores the process of punitive reform through a cultural theory lens. The existing literature focuses on high-end punishments of historical pedigree e.g. imprisonment or the death penalty. This paper instead takes as its focus low-end, contemporary punishments. In doing so, it provides original insights into the utility a cultural methodology can bring to understanding punitive reform in the digital age. It tests the applicability of Philip Smith's theory of the cultural life of punishment to case studies of the Anti-Social Behaviour Order (ASBO) and its replacements in England and Wales, the Criminal Behaviour Order and the Injunction. The ASBO was a punitive zeitgeist of its time becoming rooted in popular culture. However, it was ultimately abolished after attracting a predominantly negative cultural narrative. Thus far, after attracting some controversy at the legislative stage, the Criminal Behaviour Order and Injunction have received minimal scrutiny, despite being more problematic than their predecessor. This paper argues that the lower cultural impacts of the new punishments are responsible for the lack of scrutiny.
\end{abstract}

\section{Keywords}

Anti-Social Behaviour; ASBO; Criminal Behaviour Order; Culture of Punishment; Public Imagination; Punitive Zeitgeist

\section{Introduction}

The Anti-Social Behaviour Order (ASBO) was a punitive measure that captured the public imagination in the United Kingdom to an extraordinary degree. It was introduced in 1999, as a flagship provision of the Labour Government that had been elected the year previous. It was designed to combat the newly identified scourge of anti-social behaviour (ASB). In the sixteen years before its abolition and replacement in 2015, over 24,000 orders were issued (Home Office 2014), with 'ASBO' becoming a term imbued with significant popular cultural meaning. It functioned as a punitive zeitgeist for the period. The ASBO, however, was ultimately abolished after attracting significant criticism and a predominantly negative cultural narrative. The replacements to the ASBO, the Criminal Behaviour Order (CBO) and the Injunction, operate procedurally in a similar manner and are used to deal with the same types of behaviour as their predecessor. To the extent that they differ, the replacements provide fewer due process protections for potential recipients, therefore making them even more problematic and open to criticism. The successors caused some controversy at the legislative stage, but four years after their introduction there has been minimal critique of the CBO or Injunction. This paper argues that a key reason for this difference in levels of scrutiny is the fact that neither the CBO nor Injunction have become embedded in the public imagination. This paper discusses the wider implications that can be drawn from this case study for our understanding of the relationship between culture, punitive reform and scrutiny. 
As a theoretical basis, this paper takes as its primary influence Philip Smith (2008). For Smith (2008: 1-2) understanding the "cultural life" of punishment [is] truly important in explaining the evolution and form of penal activity':

Even where punishment looks most rationalised and bureaucratic these unruly [cultural] meanings exert their insistent and surprising influence. They can toll the bell on the outmoded technique and ring in the new, fanning the flames of scandal and celebration alike. [Punishments]... become the object of fascination, fetishism, amusement and dread. Never... closed off from public interest, punishment is always the locus of intense narrative activity and contestation within wider civil discourse. (Smith 2008: 1)

In exploring these issues, Smith (2008) advocates a case study methodology. Smith selected as his case studies punishments that have had a high impact on the public imagination and that are towards the more serious end of the punitive spectrum (e.g. the death penalty and imprisonment). This has left underresearched from this theoretical perspective the cultural life of de minimis and hybrid civil-criminal penalties. With the use of such punishments on the rise, not just in the United Kingdom, but across much of the common law world (Hendry and King, 2017), gaining a better understanding of their cultural life is important. A study of the ASBO, CBO and Injunction with very different cultural impacts to one another provides an opportunity to test the broader applicability of Smith's cultural analysis of penal evolution. Furthermore, a case study of three distinctively modern-day punishments, allows for an exploration of the utility of Smith's approach to punitive reform in the digital age.

This study adopts the four interconnected elements of Smith's (2008: 56) methodology for exploring the relationship between punishments and culture. The first, requires interpretative activity to establish the meanings attached to a particular punishment. The second, an exploration of how those meanings are 'influenced by historically embedded cultural codes, interests, hierarchies and social actions' (Smith 2008: 56). The third, an analysis of how popular culture influences wider collective representations of a punishment. The fourth, an understanding of how punishment reform can be 'explained in terms of communication and semiotics' (Smith 2008: 56).

A limitation of a Smithian cultural analysis is that in focussing on 'culture and meaning', alternative explanations of penal evolution can be ignored, in particular, those based on 'power and control' (Garland, 2009). In his writing, Smith set out to provide a generalist theory of punishment which deliberately positioned itself as an alternative to the approach of Foucault (1977) and Garland (2002) for whom the evolution of punishment is principally driven by the desire to extend control over individuals and society. As Garland (2009) identifies in his generally positive review of Smith's work, 'culture and meaning' and 'power and control' explanations need not be mutually exclusive. Both perspectives have the potential to provide complementary and rich insights into the development of a multidimensional understanding of the process of penal reform (Garland, 2006). In focussing on cultural meaning, this paper is improving understanding of the 
mechanisms by which governments seek, and sometimes struggle, to control or exert power through the punitive cultural narrative associated with reform.

A potential objection to this case study is that neither the ASBO, nor its successors, are technically penal sanctions, but rather preventative orders (MacDonald, 2003). However, this paper argues that these orders are punishments that are lacking traditional criminal legal procedural protections. Both the ASBO and now its successors involve a court imposing on recipients restrictions on their freedoms (e.g. curfews, association restrictions, geographical exclusions) justified on the basis of past misconduct and future risk of further misbehaviour. Any breach of the conditions of these orders can lead to lengthy periods of imprisonment. Additionally, as will be discussed, the cultural narrative associated with the ASBO and its successors very much frame the orders as punitive.

The next section of this paper examines how the ASBO became a zeitgeist punishment of its time. It examines how this populist cultural meaning initially protected the order from its critics, but ultimately undermined it as a form of punishment by providing opponents with the publicity to portray the order as an ineffective and unjust gimmick. The paper then turns to explore how the replacements to the ASBO were nearly not introduced after proposals quickly attracted a negative cultural narrative through a wider civil discourse campaign that was very much of the digital age. The paper then examines how despite this conspicuous start, the CBO and Injunction had made very little cultural impact almost four years after their introduction. It examines why this is the case, how this can be read as a possible success story for the Government that introduced it, and the implications of this for effective scrutiny of the reforms. The paper concludes by discussing the broader insights gained into the relationship between the cultural embeddedness of a punishment, scrutiny and reform.

\section{The ASBO: The Rise and Fall of a Zeitgeist Punishment}

According to Smith (2008: 37):

All punishments...are intended to say something about the nature of society, the qualities of the criminal, the features of a good society, the evils of crime, or the properties of the criminal justice system itself.

Whilst Smith did not have the ASBO in mind when writing this, the highly expressive attributes of the order cover all the various narrative functions mentioned by him. Before their election to government in 1997, the Labour Party was promoting their proposals for the ASBO and the related concept of ASB as tools to express its new tougher approach to crime (Tonry, 2010). Under Tony Blair, first in his role as Home Affairs Spokesperson and then as leader, the Labour Party had sought to challenge the Conservative Party's claim to be the party of law and order. In focussing on ASB, Blair and his party argued that there was a destructive quality in low-level criminality and nuisance in the compounded harm caused by the often-persistent nature of it (Burney, 2009). The harm included the feelings of urban insecurity it caused, especially amongst vulnerable individuals and populations (Ramsey, 2012). Existing criminal sanctions were seen as failing 
victims of such behaviour as they punished discrete acts of wrongdoing. The ASBO was designed to function in such a manner as to allow courts to consider compounded harm. From an expressivist perspective, the innovative nature of the ASBO was used from the outset to communicate a willingness of the Labour Party to dispense with tradition and 're-balance the system' in favour of victims (Labour Party, 1995; Tonry, 2010).

Once elected, the Labour Government made the introduction of the ASBO a priority. The initial legislation (the Crime and Disorder Act (1998 Act)) was passed in 1998. This was amended a number of times over the years. The legislation ultimately made provision for two types of ASBO. One was termed an 'ASBO on application' whereupon a court could grant an order following an application from a relevant agency (1998 Act ss1 and 1B). Agencies including the police, local authorities and social housing providers were able to apply to the relevant court for an ASBO against those aged 10 or above. The second was termed an 'anti-social behaviour order on conviction' (commonly referred to as a CRASBO) (1998 Act s1C). This could be granted by a criminal court at the sentencing stage of proceedings in addition to any criminal sentence given. Other than these differences, the two types of order functioned in the same manner. Prior to its abolition, courts could issue ASBOs where they were satisfied that (1) the individual in question had engaged in behaviour that had or was likely to cause harassment, alarm or distress to another person not of the same household and (2) it was considered necessary to grant the order to prevent further anti-social acts (1998 Act s1). The courts could attach such prohibitions to the order as they thought necessary with common conditions including curfews, geographical and association restrictions as well as prohibitions on further anti-social acts (1998 Act s1(4)). Breach of any the prohibitions was a criminal offence with a maximum penalty of five years imprisonment (1998 Act s1(10).

ASBOs did not initially prove popular with practitioners, with just over 500 issued in the first three years (October 1999-2002), rather than the annual 5,000 per year the Government had predicted (Burney, 2002). The Government responded by launching a series of high profile campaigns highlighting the evil of ASB and the utility of ASBOs as a tool for tackling it (Burney, 2009). This included the appointment of ASBO ambassadors, the provision of guidance documents and training programmes, and the gathering of data on the extent of the use of ASBOs broken down by locality (Squires, 2008). Legislation was also amended to make ASBOs easier to obtain. The changes and campaigns had some impact with statistics showing that in the following three years (2003-2005) just over 5,000 orders were obtained (Squires, 2008).

The Government campaigns directed their message not only to practitioners, but also to the wider public (Burney, 2009). Here the Government had significant success. The ASBO gained widespread popular appeal with one opinion poll from 2005 reporting that $82 \%$ of those surveyed from a sample of the general public supporting the use of the punishment (Kelly, 2012). Perhaps counter-intuitively, in that same opinion poll only $39 \%$ of those surveyed thought the orders were actually effective (Kelly, 2012). ASBOs became popular for what they symbolised or expressed rather than necessarily their instrumental value. Members of the 
public may have known very little of how the order functioned, but that did not prevent the term developing a commonly understood meaning. The popular understanding of the term became much wider than that of a technical name of a punishment. '[O]ver time, the term asbo took on a grammatical life of its own' (Hakim, 2017) becoming in common usage a noun, an adjective and a gerund. Asbo as used in public discourse came to communicate a number of messages: a populist understanding of crime and its perceived causes and cures; an emotional reaction against a certain class of individual or type of behaviour; and a method of labelling the unpopular deviant 'other' in society, particularly in relation to young people (Squires, 2008). In this there were echoes of the swift 'short, sharp, shock' aspect of youth crime punishment, one of the most culturally resonant themes of post-war penal policy (Newburn, 2005).

A striking communicative feature of the ASBO was that it facilitated public condemnation of wrongdoers to an extent not usually seen with punishments in modern day liberal democracies. A ritualistic process developed of 'naming and shaming' through the use of various 'symbols, signs, declarations, and rhetorical devices' (Garland, 1990: 250) such as leaflet drops to local residents, lurid stories in local and social media, posters in public places including on the side of buses. Invariably the publicity materials included unflattering mug-shots of the recipient and details of the contents of the order. The ASBO served as a modern form of the pillory or stocks. These raised the public profile of the ASBO and turned recipients of the orders into 'symbol[s] of infamy' (Feinberg 1970: 116). The language used in such materials encapsulated 'moral rejection, dislike, disgust, resentment, repudiation, hatred, fear, and a host of other modes of moral disapprobation' (Glasgow, 2015: 609).

With a pithy lyrical quality, 'asbo' fitted well into the digital age of banner headlines and hashtags. One could purchase t-shirts and other merchandise with the acronym blazoned across it (Kelly, 2012). The punishment became the inspiration for songs (The Beau-Nasties, 2008), true-life biographies (Montgomery, 2008) and novels (Amis, 2012). The ASBO's cultural influence brings to mind the work of Bentham (1838: 549) who stated:

A system of punishment, accompanied with emblems appropriated as much as possible to each crime, would possess an additional advantage: it would furnish allusions for poetry, for eloquence, for dramatic authors, for ordinary conversation.

The extent of the embedding of the ASBO within public culture was remarkable and likely surpassed the ambitions of its framers.

With fame though comes scrutiny. The source of this scrutiny was not primarily legislative or judicial. In the early 2000s, Parliament focussed on expanding the scope for issuing ASBOs (Kelly, 2012), whilst the courts upheld their validity holding them to be compliant with human rights ( $R$ (McCann and Others) $v$ Crown Court at Manchester and another [2002] UKHL 39). Instead, increasing scrutiny of the order came from other sources of civil discourse including civil liberties groups, academics, sections of the practice community, public action groups and 
the liberal leaning media. For critics, the acronym 'ASBO' became shorthand for an authoritarian communitarianism especially dominant during the Blair era (Squires and Stephen, 2006). The ASBO became a negative embodiment of the New Labour approach to criminal justice- a hard-line rhetoric, policymaking unsupported by evidence, the sidelining of structural causes of crime, accompanied by a disregard for traditional due process protections (Ashworth, 2004; Burney, 2009; Tonry, 2010). A rich multi-disciplinary academic critique of the ASBO gradually emerged (Ashworth, 2004; Burney, 2009; Squires and Stephen 2006). In a best-selling book, Jones (2011) criticised the common use of the term ASBO as a label as a form of middle class 'chav-hate' that seeks to marginalise and denigrate the lifestyle of the working class. ASBO became closely associated with words such as 'chav' (which entered the dictionary in the same year), 'ned' or 'pikey' as one of a collection of terms used to negatively label a certain section of the working class, particularly those out of work and in receipt of long-term benefits. A public action group calling themselves 'ASBO Concern' campaigned against what they argued was the misuse of the order and called for a full public review (Bentley, 2008). These mounting criticisms gradually undermined the populist opinion that the use of the ASBO was justified.

The publicity associated with individual ASBOs further began to undermine its justification as a form of punishment as it provided a steady supply to the media and critics of extreme or ridiculous examples of the use of the orders. Statewatch, an organisation that monitors civil liberties in Europe, hosted a page on its website entitled ASBOwatch which highlighted from 2004 to 2010 what it saw as particularly egregious examples of the use of the order. High profile examples have included a teenager who was prohibited from saying the word 'grass' anywhere in England and Wales (Carter, 2004) and a couple banned from having noisy sex in their own home (Telegraph, 2010). The subjective nature of ASB and the discretion given to courts to attach whatever prohibitions they thought necessary meant that the ASBO was a constant source of new material for the media and critics. The regularity of the reporting of these extreme examples communicated a narrative of a punishment that was open to misuse and was something of which to be suspicious or to mock.

The widespread publicity accompanying ASBOs made them a potentially powerful communicative tool for recipients. In 2006, research commissioned by the Youth Justice Board reported that some young recipients of ASBOs saw them as a 'badge of honour' (Solanki et al. 2006: 136). The recipients were in effect inverting the shaming process and were using their ASBO as a tool to boast to their peers. These recipients of the ASBO were using it to express a message of deviance, evidence that the expressive value of a particular punishment is a matter of contest.

The reputation of the ASBO was further undermined by the Labour Government's policy of gathering and publishing data on the use of the orders across England and Wales. These figures were initially used, with some success, to name and shame local authorities for not making sufficient use of the new sanction, but as time went on critics of the ASBO scrutinised the data to further undermine the credibility of the order (Squires, 2008). Most damaging of all were statistics published by the Government on the levels of breach of ASBOs. Home Office 
figures show that recipients breached 58\% of ASBOs issued between 2000 and 2013 at least once (Ministry of Justice 2014). Newspaper headlines reported the breach figures with headlines such as 'Blair's Asbo is failing to tame offenders' (Johnston, 2006). This was further evidence of Labour losing control of the narrative associated with the orders.

With the departure of Tony Blair as Prime Minister in 2007, the Labour Government of Gordon Brown promptly began to distance itself from the ASBO with the children's minster declaring that year that 'I want to live in the kind of society that puts ASBOs behind us' (Travis, 2009). No attempt was made at this point to abolish the orders and they continued to be issued after this period, although in lower numbers than previously (Ministry of Justice 2014). Not only was ASB less of a policy priority for politicians at this point in time, it was also less of a concern for the general population. Public perceptions of the extent of local levels of ASB had been on a downward trajectory over the decade. $14 \%$ of people surveyed by the Government in 2009/10 agreed with the statement that there were high levels of ASB in their neighbourhood in comparison to $21 \%$ of those surveyed in 2002/03 (Ministry of Justice, 2018). No evidence was produced to support the ASBO itself as having had a positive impact in reducing perceptions of ASB. Indeed, Squires (2008) has suggested that the cultural impact of the ASBO and the associated policy agenda played a role in initially increasing perceptions of ASB, with the subsequent fading of the ASBO in popular discourse in the late noughties contributing to the then lower level of public sensitivity to the issue. The global economic recession commencing in late 2008 played an important role in further de-prioritising crime and disorder as a matter for concern for the public and policy-makers in the UK and across the Global North (Aviram, 2015; Ipsos MORI, 2018). As part of this international trend, ASBOs and the political narrative associated with them were it seemed to be left to drift out of the public consciousness.

The phenomenon of ASB unexpectedly captured public attention again in September 2009 when British news media began reporting the inquest proceedings of a murder-suicide involving a mother and child. The mother, Fiona Pilkington, took her own life and that of her daughter, Francecca, following years of the family being subjected to ASB by local youths (Donoghue, 2013). The failure of local agencies to respond effectively to the many complaints made by Fiona Pilkington was heavily criticised in the inquest, subsequently in a number of official reports into the case and in the media (Donoghue, 2013). In response to the deaths an attempt was made in 2009 by Gordon Brown to talk the ASBO up again as part of a new get tough approach to ASB (Travis, 2009). This narrative was quickly abandoned as the order had lost its cultural credibility. It was an admission that popular culture's reading of the ASBO meant that the official message had been 'not only [been] lost in translation but also humiliated' (Smith 2008: 26). The slide from popular glory to ignominy happened strikingly quickly with the ASBO. When we think of punishments such as the death penalty or the pillory, changes of public perception were much more gradual (Smith, 2008). The speed of the ASBO's rise and downfall had much to do with the fact that the order had been introduced as a zeitgeist punishment embodying New Labour values. The order's popular appeal and level of use waxed and waned in parallel to the 
popularity of the Labour Government. Proponents and then opponents of the Government were able to use the ASBO and its deep cultural embeddedness to make broader political points.

\section{Replacing the ASBO with the $\mathrm{CBO}$ and Injunction: Changing the Narrative}

Following the 2010 election, the Labour Party left office to be replaced by the Conservative-led Coalition. In light of the deaths of Fiona Pilkington and her daughter and the subsequent deaths of others who had been subject to sustained ASB, David Askew in 2010 and Suzanne Dow in 2012, the new Government promised a victim-centric approach to ASB (Donoghue, 2013; Home Office, 2012). Proposals for new interventions such as a right for victims of ASB to petition authorities for a review of the handling of their case were promoted. As for the ASBO, the new Home Secretary, Theresa May (2010), declared that it was 'time to move beyond [it]... For 13 years, politicians told us that the government had the answer; that the ASBO was the silver bullet that would cure all society's ills. It wasn't.' Given the critique, one might have expected the government to simply abolish the ASBO. However, consensus opinion amongst practitioners, in particular the police and local authorities, was that a reformed version of the ASBO would be beneficial in dealing with difficult cases (House of Commons, 2013). They favoured replacing the order with something procedurally very similar, but offering even fewer due process protections to recipients (House of Commons, 2013). Given the negative narrative associated with the ASBO such a reform seemed destined to attract significant scrutiny and criticism.

The new government proposed replacing the ASBO on Conviction with the Criminal Behaviour Order (CBO) and the ASBO on application with an Injunction to Prevent Nuisance and Annoyance (IPNA)(Home Office, 2012). Given the similarities between the new measures and the ASBO, outlined below, it is clear that part of the role of the reform was a re-branding exercise to change the narrative associated with the ASBO. For Smith (2008), understanding the relationship between punishment and culture requires researchers to be particularly mindful of attempts to change the narrative through punitive reforms:

We can interpret... shifts in punishments as attempts to say something new, to stay on message, or to shut down contending, problematic, or embarrassing interpretative possibilities (emphasis added) (Smith, 2008:

25)

Shutting down the negative narrative and the close association of the ASBO with the Labour Party, whilst maintaining the central features of it became a key part of the Government's reforms. For the most part, the CBO operates in the same manner as its predecessor, the ASBO on Conviction. The only significant difference is that requirements, on pain of sanction, to engage in treatment for underlying causes of the behaviour may be included as part of a CBO in addition to prohibitions (Home Office, 2012). Examples of such requirements include attendance at a drug rehabilitation programme or an anger management class (Home Office, 2012). The Government promoted the order as primarily a tool to 
deal 'with the hard-core of persistently anti-social individuals who are also engaged in criminal activity' (Home Office, 2012: 25). The proposals for the CBO attracted little controversy during the passage of the legislation through Parliament. The fact that the order could only be imposed following a conviction for a criminal offence provided a level of reassurance to potential critics, as did the option to include rehabilitative conditions (House of Commons, 2013). However, as the proposed CBO was to function otherwise similarly to the ASBO, it raises many of the same human rights and due process concerns providing plenty of scope for critique (Liberty, 2011). The proposals for the CBO were, it appears, largely overlooked as the focus of scrutiny at the time was on the more controversial IPNA. The CBO from the outset made little cultural impact, allowing it to slip under the radar and avoid close examination. Following passage of the legislation, the CBO replaced the ASBO on Conviction on 20 October 2014.

The Government's proposals for replacement of the ASBO on application by what was referred to in early versions of the legislation as the IPNA became the focus of considerable publicity and critique (Home Office, 2011). The IPNA was to depart more significantly from its predecessor than the CBO was to do. Of greatest controversy was the proposed test to be used by a court in deciding whether to impose an IPNA and the standard of proof to be applied in such cases. The test for imposition of an IPNA was to have a lower threshold than that for either the ASBO or the CBO. Rather than the latters' test of causing harassment, alarm or distress to any person, the test for the IPNA was to be that the behaviour had caused, or was capable of causing, nuisance or annoyance to any person (Brown, 2013). The test had been taken from existing legislation regulating ASB in the social housing context (Brown, 2013). This test was to be coupled with the use of a lower standard of proof to satisfy a court of the need to impose an IPNA in contrast to the CBO or ASBO (Brown, 2013). The Government proposed the civil test of the balance of probabilities for the IPNA as it was a civil injunction, rather than the criminal test of beyond reasonable doubt as used for ASBOs and now CBOs (Brown, 2013). The Government defended the use of a lower standard of proof on the basis that breach of the conditions of an injunction is not a criminal offence, but amounts instead to a civil contempt of court (Home Office, 2012). Critics pointed out that whilst a finding of contempt of court does not register as a criminal offence in terms of an individual's record, a court has the authority to detain someone found in contempt to imprisonment for a period of up to two years (House of Commons, 2013). At the time of the passage of the legislation through parliament, Liberty (2011: 15) the civil liberties charity, described the proposals for the IPNA as:

A super-punitive ASBO which will be easier to obtain for even more broadly defined 'behaviour. It is likely therefore that it will be used even more than the current ASBO and the damaging ramifications of this policy even more widely felt.

These concerns initially went largely unheeded attracting little attention. It was not until the proposals drew the ire of a disparate alliance of religious, secular and civil liberties groups who established a campaign entitled 'Reform Clause 1' in 2013 that significant scrutiny of the provisions occurred. The campaign's name 
was based on the proposed test for the IPNA which was found in clause 1 of the 2013 Bill. The campaigners argued that the 'nuisance and annoyance' test would cast too wide a net and have a chilling effect on freedom of expression (Reform Clause 1, 2014). The Reform Clause 1 campaign did not become operational until late 2013 after the initial House of Commons scrutiny of the Bill. This appears to be the reason why the proposed legislation had made it through the lower house relatively unscathed with only a couple of members of parliament voicing any concern (HC Deb 10 June 2013, vol 564, col 66-127). However, when the Bill reached the upper chamber, the negative publicity surrounding the IPNA had captured widespread attention ensuring that it came under a full-scale parliamentary assault from politicians from all political backgrounds raising objections (HL Deb 8 January 2014, vol 750 col 1512-1571).

When the ASBO was first introduced to Parliament back in 1997 some academics and civil liberties groups raised similar concerns about the functioning of the proposed order as were now being raised in relation to the IPNA, but they failed to find significant support from parliamentarians (Ashworth et al. 1998). Things were different in 2013/2014. The Reform Clause 1 campaign were well organised in communicating their opposition. They established a lay-person-friendly engaging website and social media presence (Reform Clause 1, 2014; Twitter: $@$ ReformClause1). The website provided examples of the types of every day activities which the IPNA would potentially capture. Vignettes brought the issue to life ensuring the arguments were not simply abstract ones:

It's Christmas Eve and the Churchill choir are about to begin their carol singing round the village to spread good cheer and raise money for charity. Last year they earned $£ 457$ and hope to do even better this year. But if any residents decide they are 'annoying', the Parish Council might threaten them with an IPNA, which bans them from singing carols again at Christmas. (Reform Clause 1, 2014)

The vignette was written in a manner designed to communicate to readers that the proposed reforms were an attack on traditional middle class British values with reference to the 'Churchill Choir', village life and fundraising. The campaign was picked up by the mainstream media which ran stories about noisy children, nudists, carol singers, street preachers, bell ringers and charity workers all being at risk of falling under the provisions (Chorley, 2014; Monboit, 2014).

The Government originally dismissed the concerns as scaremongering nonsense (Travis, 2013), but following a heavy defeat in the House of Lords they agreed to amend the legislation (Travis, 2014). Opponents had captured the public imagination this time and been able to wrestle control of the cultural narrative from the Government before introduction of the legislation. The Government perhaps realising that the memorable acronym IPNA was contributing to the negative narrative making it sound as 'gimmicky' as the ASBO renamed the amended provision as simply the Injunction (2014 Act s1). The legislation was passed and the Injunction replaced the ASBO on application on 23 March 2015. 
With the legislation amended, the Reform Clause 1 (2014) campaign claimed victory, ending their campaign. The national media lost interest, as did critics in academia. However, all was not as it seemed. The 'nuisance and annoyance' test was not scrapped altogether, remaining for behaviour that relates to a person's 'occupation of residential premises' so presumably noisy children, carol singers or bell ringers in ear-shot of residential areas could still potentially fall foul of the new law (2014 Act s1). Examples of Injunctions granted since their introduction in 2014 demonstrate that the breadth of behaviour the courts will accept as warranting imposition and the latitude of prohibitions remain as wide as ever, with vulnerable individuals such as the homeless and young people being subject to orders (Jenkins, 2017; Williams, 2017). In claiming an outright victory, opponents of the original version of the Bill provided a legitimacy to the new legislation, which arguably it does not warrant. The eventual narrative they helped the Government to communicate was that the new legislation was a sensibly balanced compromise. In reality, the legislation goes further than the ASBO in permitting the curtailing of freedoms to engage in behaviour, which a minority may find a nuisance or annoyance. This is a powerful demonstration of the power of the public narrative to determine the perception of a punishment and influence the scrutiny it receives.

Since their introduction, the cultural lives of the CBO and Injunction have been more subdued than the ASBO. This is in part due to the new orders not being used to the same extent as the ASBO in its heyday. A Freedom of Information request by the author to the Ministry of Justice revealed that in 2017 there were 995 CBOs issued by the courts. No figures were provided, despite a request, on the number of Injunctions issued. Given the history of the ASBO, one would expect the Injunction numbers to be lower than that for the CBO. In contrast with the 2017 figures, there were 1,349 ASBOs issued in 2013 (the final year in which statistics for the order are available) and 4,122 in 2005 (the highest number granted in any one year) (Ministry of Justice, 2014). Likewise, the CBO and Injunction are not attracting media attention to the same extent as the ASBO. A publications search finds there were 3,287 , mostly local, news stories referring to CBOs and 54 to Injunctions between November 2016 and November 2018 (Nexis UK publications search, 2018). This compares to just over 13,000 news stories, with a significant minority of national media reports, referring to the ASBO in the years 2005 and 2006 (Nexis UK publications search, 2018).

Media references to the $\mathrm{CBO}$ and Injunction often contain the 'naming and shaming' narrative that was associated with the ASBO. An important distinction, however, is that news reports of the new punitive measures overwhelmingly refer to the orders in technocratic terms as the tools that facilitate restrictions being imposed on the wrongdoer. There are no taken for granted cultural meanings attached to the CBO or the Injunction. In contrast, media reports of the ASBO typically used the acronym and its widely understood cultural meaning as a way of encapsulating the essence of the story. Two representative examples are 'ASBO man is run out of town' (Brown and Skinitis, 2006) and 'Man accused of persistent begging in Keighley issued with Criminal Behaviour Order' (Rahman, 2018). 
The Conservative-led Government replaced the high profile ASBO with interventions with significantly weaker public recognition and meaning. When it came to promoting the new legal remedies, the Government focused on communicating their perceived value to practitioners rather than the public at large (Home Office, 2017). There has been no equivalent of the ASB agenda. The CBO and Injunction lack the lyrical appeal of the ASBO. Neither the CBO or Injunction refer to ASB in their title meaning that they don't encapsulate the behaviour they are seeking to control in the same way. Furthermore, there are many different types of injunction in the England and Wales, making it difficult to distinguish this one from others. Indeed some media reports make it impossible to establish which type of injunction is being referred to. Exacerbating the lack of name recognition is that court reporters in the UK tend to focus on the proceedings of the criminal courts, whereas applications for Injunctions are heard in the civil courts (County or High Court) (Moran, 2014).

The sustained critique the ASBO was subject to was in part a product of the publicity it came under as well as being a driver of further publicity. There has been no such critique of the CBO or Injunction. An academic literature review of the $\mathrm{CBO}$ and Injunction finds very little material. There appear to be a number of reasons for this. As discussed, the Reform Clause 1's declaration of victory gave the impression that the orders had been neutered. However, other factors are likely to have influenced critics as well. ASBO was a zeitgeist punishment encapsulating New Labour's approach to crime and disorder. For academics and other commentators, the study of the ASBO served as a useful focus for critiquing wider government policy. This was not the case with the Injunction or CBO. The new government never sought to make them a punitive representation of their governing philosophy. Rather, the Conservative Party packaged the reforms as a repudiation of New Labour's approach to governance. Another zeitgeist aspect of the ASBO was its association with the newly constructed phenomenon of ASB, which was to become a focus of much of the critique. The Injunction and CBO were new, but not very different tools for responding to the phenomenon of ASB. The Conservative-led Government's policy of not publishing data on the use of the new interventions also means that there is no readily available source of controversial statistics to peak interest.

Simply because the Injunction and CBO share many similarities with what had gone before does not mean that they are not worthy of analysis. Indeed, given the well-identified failings of the ASBO, the introduction of souped-up versions is arguably reason to maintain careful scrutiny. The fact that this has not been the case brings to mind Smith's (2008: 173) observation that:

The fate of punishment is never just about their efficiency or cost or humanity... but also influenced [by] the semiotic spin that attaches to objects and policies.

The notoriety of the ASBO came to undermine it and those who would use it. For critics, it expressed values of intolerance and over-policing whilst at the same time being seen as an ineffective and even counter-effective form of censure. Thanks to its high profile, it became a subject of scrutiny, attack and ridicule. The 
introduction of lower key legal remedies attracts less scrutiny from the gaze of potential critics meaning that use of the orders goes largely unchallenged.

\section{Conclusions}

This paper provides evidence of the continuing utility of culturalist explorations of penal reform and the applicability of the methodology to exploring lower-end penalties. As with any methodological standpoint, cultural approaches have their limitations and blindspots as outlined in the introduction to this paper. However, the insights gained from the use of this approach can contribute to a more rounded understanding of historical and present day punitive reform.

This cultural analysis of the ASBO and its successors, the CBO and the Injunction, has demonstrated that the extent of the cultural embeddedness of a punishment can have a significant influence on the level of scrutiny to which it will be subject and ultimately influence its fate. The relationship between cultural impact, scrutiny and penal reform is a complex one. This is partly because the cultural meaning ascribed to a form of punishment can be subject to contest and change. Different social actors can vie with one another to influence the civil discourse associated with a punishment. This includes the government, opposition politicians, the judiciary, practitioners, the news media, entertainment industries, non-governmental organisations and the public. In the modern era, narrative formation takes place through many forms of media including government propaganda, court judgments, political debate, academic critique, the news, entertainment (including fiction and non-fiction) and social media. Case studies, such as this paper, are useful in providing an insight into how the various social actors and forms of media they use can influence the punitive narrative.

Modern technological developments, including social media and the Internet more generally have contributed to democratising the civil discourse associated with punishment leading to 'a net growth in broader societal reflexivity over criminal justice process' (Smith 2008: 14-15). This has made it more difficult for the state to maintain control of the narrative associated with punishment 'with reforms orientated around meaning control as much as the regulation of deviance itself' (Smith 2008: 15). The ASBO and its successors have been creatures of this contemporary era, with the digital environment an important setting in shaping their cultural meaning. 'ASBO' quickly became a buzzword of its time, with its lyrical acronym fitting well in an era of tabloid headlines and hashtags. It became a punitive zeitgeist, encapsulating intolerance to certain forms of behaviour and individuals, before ultimately becoming synonymous with over-zealous reach by the state. More recently, the Conservative-led Government's plans to introduce the Injunction were almost derailed due to a campaign, which had a slick online presence. The recent history of the Injunction demonstrates how the punitive narrative can change rapidly in the modern era. However, it is important to note that modern communication technology does not guarantee that punishments will be scrutinised through civil discourse, even where they are normatively controversial. In the age of distraction, where attention spans are decreasing and news-cycles quickly move onto the next story, punishments that make little impact on the public imagination can too easily evade scrutiny. Today, both the 
CBO and Injunction are subject to minimal critical discussion, despite being just as troubling, if not more so, than their predecessor.

For government, creating a high profile punishment can be a double-edged sword. Lawmakers can use the introduction of such a punishment to communicate a distinct message to the public. This opportunity to establish a new expressive narrative is heightened, if the (mis)behaviour, which is to be subject to punitive measures, is, itself, a new object of the disciplinary gaze of the state. The innovative nature of the ASBO proved to be just such a form of punishment. The ASBO was initially an example of this when it came to be understood as having a public meaning of being a ready identifier of anti-social individuals being deserving of censure. However, a high profile raises the likelihood that a punishment will become 'an object of fascination, fetishism, [and] amusement' (Smith 2008: 1) which encourages competing value narratives. The high profile of the ASBO helped to bring to the fore the troubling features of it which ultimately assisted in heralding its demise. In abolishing the ASBO, the Conservative-led Government intended to close down this negative narrative. Their proposals for what was to be called the IPNA quickly captured the public imagination, but the Government lost control of the narrative and the resulting legislation created two punitive measures that have had a remarkably low public profile. This could be viewed as a failing in that a role of punishment is to influence norms of behaviour through communication to the public not just the perpetrator. However, inconspicuousness or indifference can be useful to the state as it reduces the likelihood of scrutiny. Four years after the introduction of the CBO and Injunction, we know very little about how these orders are being used or misused, with only basic statistics gained through Freedom of Information requests and local media reports providing evidence that they continue to be utilised.

As scholars of punishment, we can perceive our discipline as one that is not unduly influenced by populist sentiment in choosing which punitive measures to subject to critical examination. However, this case study provides evidence that as a discipline we can overlook punitive measures which objectively we would agree are worthy of greater analysis, but which have failed to become embedded in popular culture. The CBO and Injunction serve as cautionary reminders to keep within our gaze punishments with lower cultural impacts to ensure they do not evade scrutiny.

\section{References}

Amis M (2012) Lionel Asbo: State of England. London: Vintage Books. 
Ashworth A (2004) Social Control and "Anti-Social Behaviour": The Subversion of Human Rights Law Quarterly Review 120: 263-291.

Ashworth A, Gardner J, Morgan R, Smith A, von Hirsch A and Warik M (1998) Neighbouring on the Oppressive: The Government's Anti-Social Behaviour Order Proposals. Criminal Justice 16(1):7-14.

Aviram H (2015) Cheap on crime: Recession-era politics and the transformation of American punishment. Berkeley: University of California Press.

BBC Online (2014) 'Naked rambler' Stephen Gough jailed for Asbo breach'. BBC Online. 7 October 2014, available at: http://www.bbc.co.uk/news/uk-englandhampshire-29528084

BBC Online (2015) 'Nottingham City Council takes out injunction to 'silence' campaigner.' BBC Online, 30 October 2015, available at:

http://www.bbc.co.uk/news/uk-england-nottinghamshire-34670355

Bentley H (2008) 'A short history of the asbo.' The Guardian. 27 August 2008. available at: https://www.theguardian.com/society/2008/aug/27/asbo.timeline

Bentham J (1838) The Works of Jeremy Bentham: Part II. Edinburgh: William Tait.

Bone H (2016) 'Harrogate woman handed Criminal Behaviour Order for religiously aggravated offences.' Harrogate Advertiser, 17 November 2016, available at: http://www.harrogateadvertiser.co.uk/news/crime/harrogatewoman-handed-criminal-behaviour-order-for-religiously-aggravated-offences$\underline{1-8244237}$

Brown K J (2013) Replacing the ASBO with the injunction to prevent nuisance and annoyance: A plea for legislative scrutiny and amendment. Criminal Law Review 623-639.

Brown D and Skinitis A (2006) 'ASBO Man Run Out of Town.' The Times (London), 27 September 2006, p. 10.

Burney E. (2002) Talking Tough, Acting Coy: Whatever Happened to the Antisocial Behaviour Order? The Howard Journal of Criminal Justice 41(5): 46984.

Burney E (2009) Making People Behave: Anti-Social Behaviour, Politics and Policy. Cullompton: Willan Publishing.

Carter H (2004) 'Don't say grass, boy is warned.' The Guardian, 15 January 2004, available at http://www.theguardian.com/uk/2004/jan/15/helencarter

Chakrabarti S (2006) British Institute of Human Rights Lunchtime Lecture. London: Liberty. 
Chorley M (2014) 'Nudists, bell ringers, noisy children and carol singers defeat government attempt to outlaw 'annoying behaviour', Mail Online, 9 January 2014, available at: http://www.dailymail.co.uk/news/article-2536396/Nudistsbell-ringers-noisy-children-carol-singers-defeat-government-attempt-outlawannoying-behaviour.html ;

Donoghue J (2013) Reflections on risk, anti-social behaviour and vulnerable/repeat victims. British journal of Criminology 53(5):805-23.

Feinberg J (1970) 'The Expressive Function of Punishment' in J Feinberg Doing and Deserving: Essays in the Theory of Responsibility. Princeton: Princeton University Press.

Field F (2003) Neighbours From Hell: The Politics of Behaviour. London: Politico's Publishing.

Foucault M (1977) Discipline and Punish: The Birth of the Prison. London: Allen Lane.

Garland D (1990) Punishment and Modern Society: A Study in Social Theory. Oxford: OUP.

Garland D (2002) The Culture of Control: Crime and Social Order in Contemporary Society. Oxford: OUP.

Garland D (2006) Concepts of Culture in the Sociology of Punishment. Theoretical Criminology 10(4) 419-447.

Garland D (2009) A Culturalist Theory of Punishment? Punishment and Culture, Philip Smith. Chicago, IL: University of Chicago Press. Punishment and Society 11(2) 259-268.

Glasgow J (2015) The Expressivist Theory of Punishment Defended. Law and Philosophy 34: 601-631.

Hakim D (2017) 'Arriving in London, Learning to Fear the ASBO.' New York Times, 27 July 27, 2017 p. 6.

Hendry J and King C (2017) Expediency, legitimacy, and the rule of law: a systems perspective on civil/criminal procedural hybrids. Criminal Law and Philosophy 11(4) 733-57.

Home Office (2011) More Effective Responses to Anti-Social Behaviour. London: Home Office.

Home Office (2012) Putting Victims First: More Effective Responses to Anti-Social Behaviour. London: Home Office. Cm 8367. 
Home Office (2014) Anti-Social Behaviour Order Statistics, available at: https://www.gov.uk/government/publications/anti-social-behaviour-orderstatistics-england-and-wales-2013/anti-social-behaviour-order-statisticsengland-and-wales-2013-key-findings

Home Office (2017) Anti-social Behaviour, Crime and Policing Act 2014: Reform of anti-social behaviour powers Statutory guidance for frontline professionals. London: Home Office.

House of Commons (2013) Anti-Social Behaviour, Crime and Policing Bill: Written Evidence. London: HMSO.

Ipsos MORI (2018) Issues Index 2007-onwards. Available at: https://www.ipsos.com/ipsos-mori/en-uk/issues-index-2007-onwards

Jenkins R (2017) 'Keep out Teenager ordered to stay away from parts of St Paul's'. Gloucestershire Echo, 29th September 2017, p. 2,

Jones 0 (2011) Chavs: The Demonization of the Working Class. London: Verso.

Johnston P (2006) 'Blair's Asbo is failing to tame offenders' The Telegraph, 7 December 2006, available at:

https://www.telegraph.co.uk/news/uknews/1536197/Blairs-Asbo-is-failing-totame-offenders.html

Kelly J (2012) 'ASBO - The End of an Era', BBC Online, 23 May 2012, available at: http://www.bbc.co.uk/news/magazine-18164426

Labour Party (1995) A Quiet Life: Tough Action on Criminal Neighbours. London: Labour Party.

Liberty (2011) Liberty's Response to the Home Office's Proposals on More Effective Responses to Anti-Social Behaviour. London: Liberty.

Lindsell J (2013) 'Super-ASBOs will make it super-easy to ban just about anything.' The Independent 4 December 2013, available at:

https://www.independent.co.uk/voices/comment/super-asbos-will-make-itsuper-easy-to-ban-just-about-anything-8982793.html

May T (2010) 'Home Secretary's speech on moving beyond the ASBO.' 28th July 2010, available at: https://www.gov.uk/government/speeches/crime-homesecretarys-speech-on-moving-beyond-the-asbo-28-july-2010

Macdonald S (2003) The Nature of the Anti-Social Behaviour Order-R (McCann \& Others) v Crown Court at Manchester. The Modern Law Review 66(4):630-9.

Millie A (2008) Anti-Social Behaviour. Maidenhead: Open University Press. 
Ministry of Justice (2014) Statistical Notice: Anti-Social Behaviour Order (ASBO) Statistics - England and Wales 2013. London: Ministry of Justice. Available at: https://www.gov.uk/government/uploads/system/uploads/attachment data/fi le/355103/anti-social-behaviour-order-statistical-notice-2013.pdf

Monbiot G (2014) 'At last, a law to stop almost anyone from doing almost anything.' The Guardian, 6 January 2014, available at: http://www.theguardian.com/commentisfree/2014/jan/06/law-to-stopeveyone-everything

Montgomery L (2008) ASBO: A Mother's Story. Brentwood: Chipmunk publishing. Moran, L J (2014) Mass-mediated 'open justice': court and judicial reports in the press in England and Wales. Legal Studies 34(1): 143-166.

Newburn T (2005) 'Back to the future? Youth crime, youth justice and the rediscovery of 'authoritarian populism'. Pilcher J and Wagg S (eds) In Thatcher's Children? Politics, Childhood And Society In the 1980s and 1990s (pp. 69-84) Abingdon: Routledge.

Rahman, M (2018) 'Man accused of persistent begging in Keighley issued with Criminal Behaviour Order' Bradford Telegraph and Argus, $5^{\text {th }}$ August 2018.

Ramsey P (2012) The Insecurity State: Vulnerable Autonomy and the Right to Security in the Criminal Law (Oxford: OUP).

Reform Clause 1 (2014) Reform Clause 1: Fell Free to Annoy Me. Available at: http://reformclause1.org.uk

Smith P (2008) Punishment and Culture. London: University of Chicago Press.

Solanki A R, Bateman T, Boswell G \& Hill E (2006) Anti-Social Behaviour Orders. London: Youth Justice Board.

Squires P and Stephen D E (2005) Rougher Justice: Anti-Social Behaviour and Young People. Cullompton: Willan Publishing.

Squires P (2008) The Politics of Anti-Social Behaviour British Politics 3: 300-323.

Statewatch, 'ASBOwatch: Monitoring the Use of ASBOs' available at: www.statewatch.org/asbo/asbowatch-extreme.htm

The Beau-Nasties (2008) 'The ASBO Song.' Album ‘\#6674273’ (CD).

The Telegraph (2010) 'Neighbour with sex Asbo arrested for noisy sessions.' The Telegraph, 21 March 2010, available at: http://www.telegraph.co.uk/news/newstopics/howaboutthat/7494294/Neighb our-with-sex-Asbo-arrested-for-noisy-sessions.html 
Tonry M (2010) The costly consequences of populist posturing: ASBOs, victims, 'rebalancing' and diminution in support for civil liberties. Punishment \& Society 12.4: 87-413.

Travis A (2009) 'The return of the asbo.' The Guardian, 29 September 2009, available at: https://www.theguardian.com/society/2009/sep/29/asbo-browncrime-crackdown

Travis A (2013) 'New asbo threat to carol singers is 'complete nonsense', says minister.' The Guardian, 29 November 2013, available at:

http://www.theguardian.com/society/2013/nov/29/asbo-carol-singersnonsense-norman-baker

Travis A (2014) 'Nuisance and annoyance' injunctions abandoned after Lords defeat.' The Guardian, 23 January 2014, available at:

http://www.theguardian.com/law/2014/jan/23/nuisance-and-annoyanceinjunctions-abandoned-lords-defeat

Williams K (2017) 'Beggar Banned From Town Centre' Daily Post, $8^{\text {th }}$ September 2017, p. 13. 